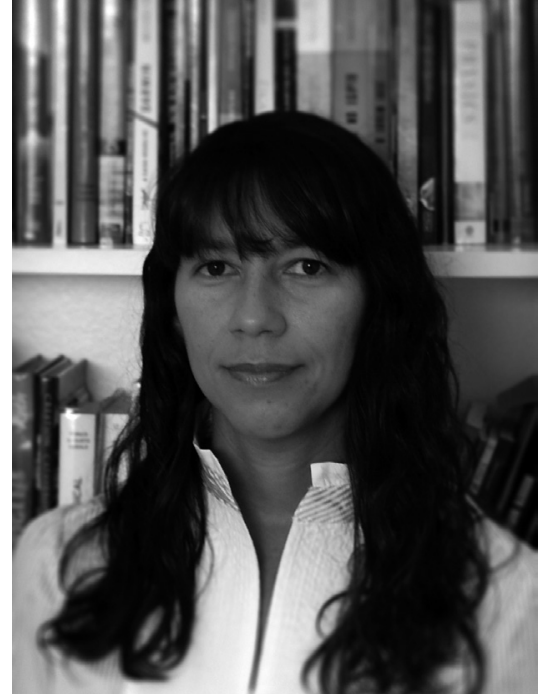

(C) Arquivo Pessoal

${ }^{1}$ Research Centre Didactics and Technology in Education of Trainers - CIDTFF - University of Aveiro, Portugal.

dayneri@ua.pt

${ }^{2}$ The School of Health, University of Aveiro (ESSUA), Aveiro, Portugal. mrua@ua.pt

${ }^{3}$ Federal University of Goiás, Goiás, GO, Brazil. ellen.synthia@gmail.com

${ }^{4}$ Research Centre Didactics and Technology in Education of Trainers - CIDTFF - University of Aveiro, Portugal. ISLA University, Vila Nova de Gaia, Portugal. ULP University, Porto, Portugal. apcosta@ua.pt

\section{Qualitative research in health: contributions to education, profession, family, citizenship and social interaction}

\section{Dayse Neri de Souzaํ, Marília Rua², Ellen Synthia Fernandes Oliveira³,} António Pedro Costa ${ }^{4}$

The articles published in the current Special Edition were selected after a rigorous evaluation. Despite being chosen because of their accuracy and quality of the studies conducted, not because of the subjects addressed, the themes that have become enriching for this publication were clearly cohesive and sequential.

Being qualitative studies, the articles focus, as recommended by experts in the field ${ }^{1,2,3,4,5,6}$, on the duty to reveal "truths", values, beliefs, representations, habits, deep knowledge of their experiences and the way people construct meanings and relationships.

It is indeed important to note that over the last years qualitative studies in health have achieved their due recognition. The path studies of this nature have walked is notoriously difficult. Authors like Sarma ${ }^{2}$ have pointed out the challenging path that encounters misleading allegations and the lack of understanding of the paradigmatic differences between the two research types - Quantitative and Qualitative. According to the author, qualitative studies are accused of being mere story tales, anecdotes and researchers' personal impressions, labelled as non-scientific due to the fact that their results cannot be generalised.

The discussion about qualitative studies not being able to be generalised is an old one, preceding the golden years of the 1920s with Malinowski ${ }^{7}$, who has become a pioneer in his area by describing the collection of field data in an organised and systematic way, and his contributions to the discussion.

In spite of the sharp criticism, one should reflect on the perspectives given by authors such as Deslandes and Assis ${ }^{8}$, and $\mathrm{Amado}^{9}$, who note the need for these studies to comply with their own characteristics but also the accuracy and quality of science. Boavida and Amado ${ }^{10}$, and Deslandes and Assis ${ }^{8}$ warn us that the compliance of reliability, validity and credibility criteria in qualitative studies is a great advantage that "allows a greater reliability of its constructs to the empirical reality and to the experience of the individuals surveyed"8:204.

Facing a slow but steady and robust growth, important contributions of qualitative studies conducted by health professionals have been published in several health journals ${ }^{11,12}$.

The themes of the articles in the current number range from health courses and training of doctors and nurses to health and disease, family experience and suffering, eating habits, the role and importance of social networks for nursing and family, as well as nurses' experiences and views and the voice of the community health agent.

Within the scope of health training based on the curricula and adaptation to reality, the article Understanding the national syllabus in light of the overarching training principals in health care in Brazil indicated an analysis of the pedagogical projects, highlighting the guiding principles of training in Nursing, Pharmacy, Medicine, Nutrition and Odontology courses, from the technical and ethical-social factors to professional practice and interdisciplinarity. In this respect, the results of the study Analysis of teaching-service integration activities performed in health courses at the Federal University of Babia revealed the importance of in- 
tegrating university studies into health services, taking into account the need to make changes in education in line with the innumerable primary health care units.

The article entitled Medical and Nurses training of Family Health Strategy regarding workers' health aimed to understand the perception that the doctors and nurses who make up the Family Health Strategy service team have of occupational diseases. It also stresses the importance of offering the worker a better service and of a work-health-disease relationship.

Concerning the communication skills to be developed in the context of nursing education, the study The development of communication skills and the faculty's role from the nursing student's perspective stresses that students point out appreciation as an essential and indispensable skill for a safe and quality practice with patients. Associated with the communication competence, the study of the Nursing teachers' perceptions of care: a construction based on heidegger aims to make care the very existence of the nursing profession, since, in the interrelational relationship with the person being cared for, the subjectivity of sensitive care is displayed to the objectivity of scientific care.

Within the context of communication skills and nursing care, lies the study The Experience of being ill: palliative care given the impossibility of cure, featuring a terminally ill patient's reflection and how to face the impossibility of healing and palliative care as a more comfortable choice in the end-of-life process.

Regarding the application of the concept of adherence to the treatment of the psychosocial perspective in public mental health in Brazil, the study The applicability of the concept of treatment adherence in the context of the Brazilian mental health system revealed, through a literature review in some electronic databases, the lack of knowledge of mental health laws and the acceptance of the mental asylum assistance model.

In addition to the adherence side, and considering the patients' views, the article Perception of hypertensive patients about their non-adherence to the use of medication showed, regarding drug therapy, the need to invest in more effective strategies in the care of hypertensive patients, disclosing that the reasons for non-adherence are justified by the excessive amount of medication, forgetfulness and lifestyle changes. In order to know the patients' opinions, the study on the Social Representations of Gynecologic Cancer Screening in Ecuadorian Women highlighted the knowledge of the women attending the gynaecological cancer screening programme and the drama of making the exams associated with a traumatic experience.

Still regarding the patients' perceptions of diseases, the study 30 years later: social representations about AIDS and sexual practices of residents in rural cities aimed to raise awareness of the need to intensify information and intervention campaigns about the disease, taking into account the fact that the respondents from rural areas have no understanding of the invulnerability of the contamination by HIV virus.

Concerning the act of caring, the importance of health professionals in supporting the caregiving family is revealed in the article The family experience of care in chronic situation. This task falls on the family taking care both of themselves and their relative with a chronic disease, in a perspective of conformation, family support and other close persons performing this function.

Within the health professionals' support to family and patients outlook, arises the moral suffering position of the professionals who experience constraints in the Family Health Strategy, when they encounter situations that compromise their practice and go against the values ethical their job requires, such as social vulnerability, poor economic conditions and fragility of the Health System. This fact was pointed out by the study presented in the article Moral Distress and the Family Health Strategy: daily life experiences.

Regarding the approach to food, the study about the Brazilian native population Changing dietary babits among Akwẽ Xerente revealed the changes in their eating habits due to the influence of modern culture, such as the use of electricity and technologies. Foods that used to be grown by themselves, for example, cassava and yam, have been replaced by industrial goods.

With respect to innovative methods in the qualitative research, we present the study Minimum Map of Institutional Social Network: a multidimensional strategy for research in Nursing, which emphasizes the use of this yet unusual methodology but that has become important in the links and connections established between the institution under research and the organised groups. The map provides a better view of the relationships and contexts, and complies with the government guidelines on health policies. It has also responded to the needs in the areas of health research and practice, particularly in nursing. 
Social Networks have contributed to family, social and hospital support, reinforcing the role of technologies and their application in the health sector by use of new strategies. The article entitled The Social Networks of Family Caregivers during Hospitalization of Children pointed out this is an essential means of support in the relationships established between the hospital, with the hospital health team, and other external services.

Any information on health-disease and knowledge of how the population can access emergency health services and how they operate is valuable. Creating an educational tool to understand the Mobile Emergency Medical Service may contribute to change and decrease risk situations in case of distress calls. Thus, the study Educational topics for students from the perspective of professionals from the Mobile Emergency Service, that promotes health education in the emergency care area closely with school populations, addresses the possibility of clarifying how the Mobile Emergency Medical Service operates and how to minimize problems in emergency cases.

Death and mourning have been one of the most distressing problems health professionals have to deal with every day. The article Taking care of dying newborns and their families: Nurses' experiences in the neonatal intensive care unit reports the experiences lived by nurses of the Neonatal Intensive Care Units when taking care of newborns who are dying and their families. It also stresses the suffering experienced, mainly because getting involved in this situation is inevitable. These professionals express the sadness, suffering, need to learn how to deal with the situation and feeling of accomplished duty.

To continue the commitment of nurses, giving an answer to the population's life and health quality in a broad way and considering the holistic aspects has been one of the main objectives. The article Analysis of one Family Clinics, a view of the service nurses reported an innovative proposal implemented in Rio de Janeiro, sustained by the Family Health Strategy and replicated in the municipality of Cuiabá. The proposal is based on the analysis of the service at the Family Clinic, offered and envisioned by nurses who are part of the team, according to the practice and the provisions of the Amplified and Shared Clinic, which targets the autonomy of the health service user.

Mental health care and the psychiatric reform in Brazil need more attention when it comes to their implementation, that is, there is a large gap between the programme initiatives and the public policy recommendations. This fact is revealed by the last article in this issue, entitled Psychological distress and community approach in the voice of community health agents. The study also highlights the logistics operational difficulties faced by the teams of the Centres for Psychosocial Attention and the Primary Health Care staff, especially when facing the immense diversity found in the Brazilian States/Municipalities. In addition, there is the issue of "different people" who are prejudiced and not accepted by their family or community. Within the context of the study, Community Agents working closely with a Primary Health Care Unit were invited to participate. Their statements reveal how the community sees a person with mental health problems and how patients deal with prejudice and exclusion problems.

Bearing in mind the enriching scientific contributions of the realities described in the articles, this Special Issue covers the recognition of health professionals' training and education, the role played by the health professionals and health workers with patients, family members and the community, as well as the connection between care and technologies as communication facilitators amongst the intervening parties. It is also worth noting that researchers followed the methodological strategies involved in qualitative research, regarding the diversity of data collection tools and analysis types, as well as the accuracy present at all stages of the research process.

\section{REFERENCES}

1. Minayo CS, Delandes SF. Caminhos do pensamento: epistemologia e métodos. 3.ed Edição. Rio de Janeiro: Fiocruz, 2013.

2. Sarma SK. Qualitative Research: examining the misconceptions, South Asian Journal of Management. 2015, 22(3): 176-191.

3. Minayo MC, Sanches O. Quantitativo-qualitativo: oposição ou complementaridade? Caderno de Saúde Pública, 1993, 9(3):239-262.

4. Turato ER. Métodos qualitativos e quantitativos na área da saúde: definições, diferenças e seus objetos de pesquisa. Rev. Saúde Publica, 2005; 39(3): 507-514.

5. Bogdan RE.; Biklen S. Investigação qualitativa em educação. Porto: Porto Editora, 1994.

6. Denzin NK, Lincoln IS . O Planejamento da Pesquisa qualitativa: Teorias e Abordagens. 2. ed. Porto Alegre: Artmed, 2006 
7. Malinowski B. Argonauts of the werten pacific na account of native enterprise, and adventure in the arquepelagoes, of Melanesian new Guinea. Londo: Forgotten Books, 2013.

8. Deslandes S, Assis SG. Abordagens quantitativa e qualitativa em saúde: o diálogo das diferenças. In: Minayo, MCS, Deslandes, SF. Caminhos do pensamento: epistemologia e método. 3.ed. Rio de Janeiro: Fiocruz, 2013. p. 195-222.

9. Amado J. Manual de investigação qualitativa em educação. 1.ed. Coimbra: Imprensa da Universidade de Coimbra, 2013.

10.Boavida J, Amado J. Ciências da Educação - epistemologia, identidade e perspectivas. 2.ed. Coimbra: Imprensa da Universidade de Coimbra, 2008.

11. Taquette SR, Minayo MCS. Características de estudos qualitativos conduzidos por médicos: revisão da literatura, Ciência e Saúde Coletiva. 2015 20(8), p. 2423-2430.

12. Britten N. Making sense of qualitative research: a new series. Med Educ, 2005, 39 (1), p. 2-6. 